\title{
HOUSING MORTGAGE IN THE RUSSIAN FEDERATION IN Q2 2015
}

\author{
G.Zadonsky
}

In Q2 2015, housing mortgage loans (HML) totaling to Rb 242.53bn were originated which was $44.23 \%$ lower than the same index for Q2 2014. The volume of residual debt on HML as of 1 July 2015 constituted Rb 3.608 trillion. The share the ruble stale debt on HML in the residual debt came to 0.98\% as of 1 July 2015 against $0.92 \%$ as of 1 April 2015. As of 1 July 2015, the share of debt on default HML with past-due payments of 180 days and more went up to $2.08 \%$ of the total debt amount. The weighted average interest rate on ruble-denominated HML issued in June 2015 constituted 13.29\% and the weighted average interest rate for half year - 14.4\%. In the course of Q2 2015, in the framework of the state program of subsidizing interest rates of the residential mortgage loans extended for purchasing accommodation in the new housing construction sector (interest rate not more than 12\%) a total number of 52 thousand loans were originated totaling to Rb 90bn which constitute 38\% of the total HML amount originated over this period.

According to the Central Bank of Russia in H1 2015, credit institutions issued 288,032 mortgage loans (ML) in the amount of Rb 470.56bn. Of that amount, in Q2 credit institutions originated $149,079 \mathrm{ML}$ to the tune of Rb 247.10bn. In H1 2015, 280,485 mortgage loans totaling to $\mathrm{Rb} 460.66 \mathrm{bn}$ were originated, of which in Q2 - 145,301 mortgage loans were originated totaling to $\mathrm{Rb} 242.53 \mathrm{bn}$. The amount of $\mathrm{HML}$ originated in Q2 was by $44.23 \%$ less the amount of loans originated in Q2 2014, whereas the amount of HML originated in Q2 2014 by 37.8\% exceeded the data for Q2 2014. The share of foreign currency denominated mortgage loans originated in $\mathrm{H} 12015$ in the aggregate mortgage portfolio constituted $0.37 \%$ in monetary terms against $0.48 \%$ for $\mathrm{H} 1$ 2014. The amount of residual debt on $\mathrm{HML}$ as of 1 July 2015 came to Rb 3.61bn of which $\mathrm{Rb}$ 3.49 trillion on loans denominated in rubles (Fig. 1). At the same time, the amount of debt outstanding on $\mathrm{HML}$ in foreign currency of the overall debt constitutes $3.41 \%$, down 0.09 p.p. as of 1 July 2014.

According to the CBR, stale debt on HML as of 1 July 2015 totaled to $\mathrm{Rb} 53.0 \mathrm{bn}$ (Rb34.11bn in ruble loans and $\mathrm{Rb} 18.89 \mathrm{bn}$ in loans in foreign currency). Whereas, stale debt on HML in rubles as of 1 July 2015 went up in comparison with stale debt as of 1 April 2015 by $8.83 \%$ in monetary terms, and as a share on residual debt $(0.98 \%)$ went up by 0.06 p.p. Stale debt on $\mathrm{HML}$ in foreign currency during the same period increased by $0.48 \%$ in monetary terms and increased by 2.43 p.p. as a share of residual debt (16.32\%). (Fig.2).

According to the CBR, total debt on $\mathrm{HML}$ without past-due payments as of 1 July 2015 came to $\mathrm{Rb}$ 3,392.49bn, going up compared to 1 July 2014 by $R b$ 498.46bn and decreasing from the total debt by 1.28 p.p. to $94.02 \%$ (Fig.3). Within the same period, debt on HML with 1 to 30 days with past-due payments

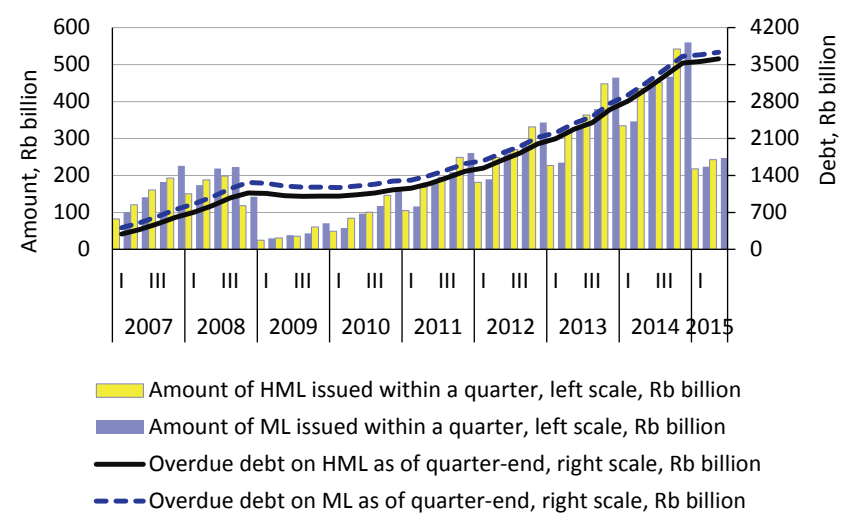

Source: Central Bank of Russia

Fig. 1. Dynamics of residential mortgage lending

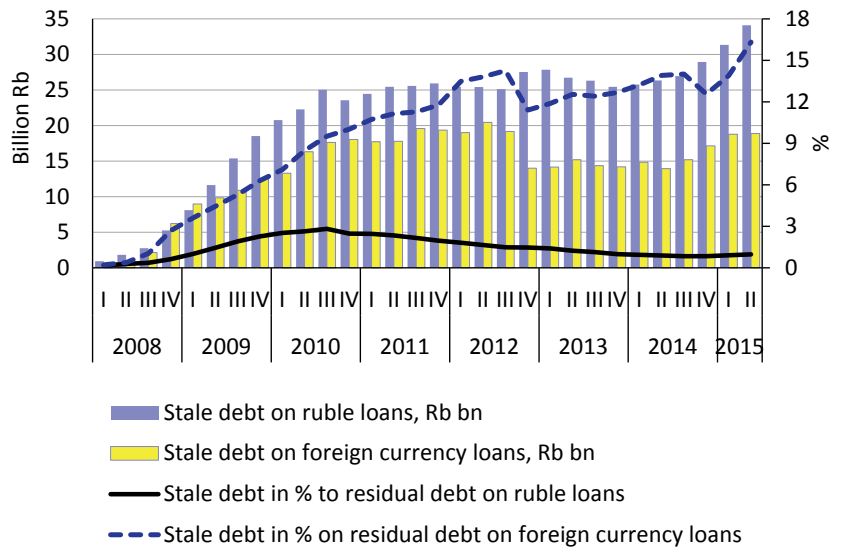

Source: Central Bank of Russia

Fig. 2. Dynamics of stale debt on HML as of quarter-end

reached $\mathrm{Rb} 90.93 \mathrm{bn}$, up $\mathrm{Rb} 27.157 \mathrm{bn}$ and constituted $2.52 \%$ of the overall debt, by 0.43 p.p. exceeding the indictor as of 1 July 2014. Regarding default HML (loans with overdue payments of 180 days and more) the debt went up by $\mathrm{Rb} 22.52$ bn and came to $2.08 \%$ of 
the overall indebtedness, which by 0.35 p.p. exceeds corresponding indicator as of 1 July 2014 (Fig.3).

According the CBR in H1 2015, the weighted average interest rate on $\mathrm{HML}$ in rubles extended within a month reached its highest (14.71\%) level in February 2015, and in June fell to $13.29 \%$ (Fig. 4). The weighted average interest rate on HML extended from the turn of the year in rubles for the period-end results for $\mathrm{H} 1$ 2015 came to $14.04 \%$.

According to the CBR in $\mathrm{H} 12015$, the lowest weighted average interest rate in the mortgage lending market denominated in rubles provided by credit institutions ranked from 21 to 200 place by their asset size came to $13.8 \%$, meanwhile depository institutions ranked from 201 to 500 place by asset size has the highest rate of $16.6 \%$ in contrast to the average market interest rate of $14.04 \%$. The weighted average interest rate on $\mathrm{HML}$ in foreign currency extended from the turn of the year, within H1 2015 constituted 10.1\% against 9.5\% for the same period of 2014. The lowest interest rate in foreign currency of the major five banks as of 1 July 2015 constituted $8.4 \%$ and the highest interest rate of $12.8 \%$ was true of the banks ranked 201-500.

The weighted average loan period for mortgage loans originated from the turn of the year, as of 1 July 2015 fell in comparison with 1 April 2014 on the ruble loans by $0.40 \%$ to 14.44 years, and on the loans in foreign currency over the same period grew by $20.53 \%$ to 4.21 years.

The average loan amount in rubles originated in $\mathrm{H} 1$ 2015 dwindled compared to $\mathrm{H} 12014$ across all regions of the Russian Federation except Moscow. As in H1 2014, the lowest loan amounts (Rb1.29mn) were originated in the Volga federal region, and the largest loan $(\mathrm{Rb} 3.69 \mathrm{mn})$ amounts were issued in Moscow.

The weighted average interest rates on rubledenominated HML as of 1 July 2015 went up compared to 1 July 2014 across all regions with the lowest rate of $13.85 \%$ in St. Petersburg (Fig. 5).

According to the Ministry of Finance of Russia, in the framework of the State Program on interest rates subsidization for newly constructed building mortgage loans (rate not more than 12\%) over Q2 2015 52,000 mortgage loans were originated totaling over $\mathrm{Rb}$ $90.0 \mathrm{bn}$, which constitutes $38 \%$ of the originated mortgage loans amount over this period.

Over January-July 2015, 12 mortgage-backed securities issues totaling to $\mathrm{Rb} 52.88 \mathrm{bn}$ were placed in the residential mortgage-backed securities market. In the course of H1 2014, 12 mortgage-backed securities issues were originated with aggregate volume of $\mathrm{Rb}$ 108.0bn.

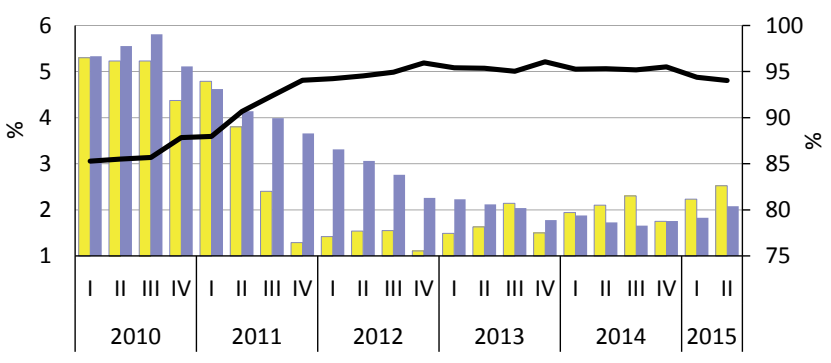

$\square 1$ to 30 days past due in $\%$ to total debt, left scale

180 days past due, left scale

-Overdue payment-free mortgage loans in \% to total debt, right scale

Source: Central Bank of Russia

Fig. 3. Debt on HML grouped by payment delay terms as of quarter-end

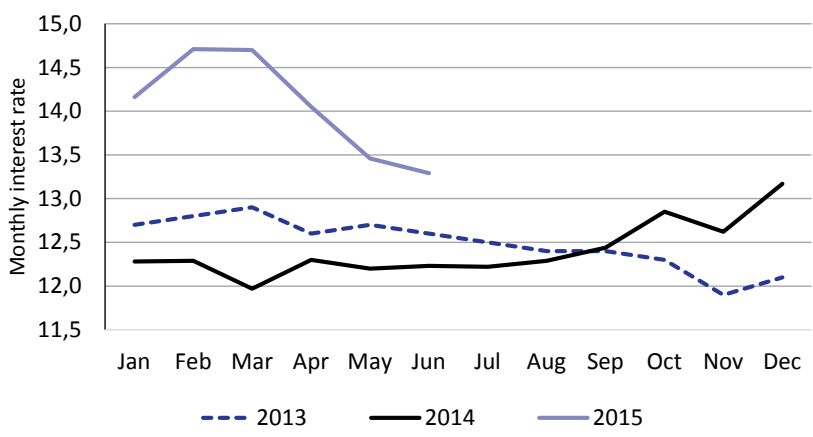

Source: Central Bank of Russia

Fig. 4. Average interest rate on $H M L$ in rubles issued within month

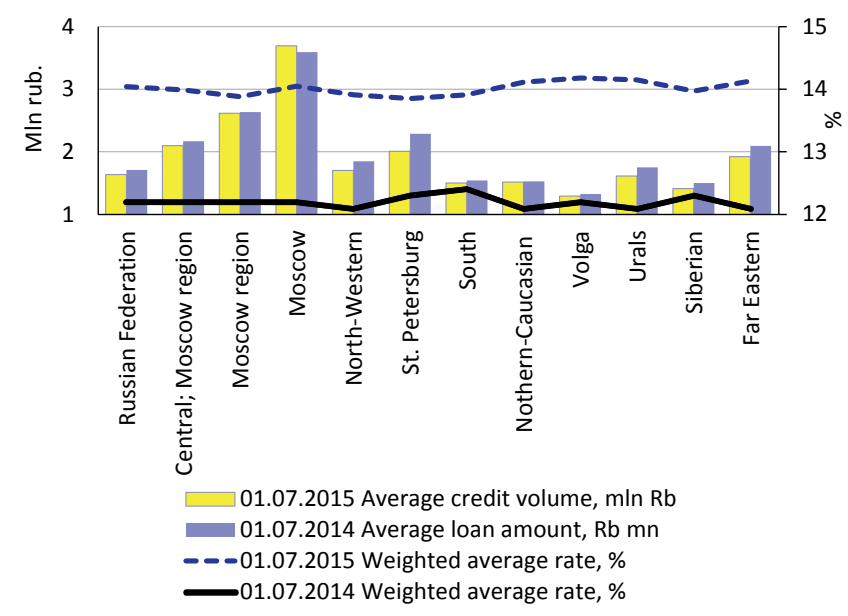

Source: Central Bank of Russia

Fig. 5. Weighted average data on mortgage loans in rubles originated from the turn of the year 